\title{
Restoring an eroded legitimacy: the adaptation of nonfinancial disclosure after a scandal and the risk of hypocrisy
}

Restoring an eroded legitimacy

Marco Bellucci

Department of Economics and Management, University of Florence, Florence, Italy Diletta Acuti

Department of Marketing, University of Portsmouth, Portsmouth, UK

Lorenzo Simoni

Department of Economics and Business Studies, University of Genoa, Genoa, Italy, and

Giacomo Manetti

Department of Economics and Management, University of Florence, Florence, Italy

\begin{abstract}
Purpose - This study contributes to the literature on hypocrisy in corporate social responsibility by investigating how organizations adapt their nonfinancial disclosure after a social, environmental or governance scandal.

Design/methodology/approach - The present research employs content analysis of nonfinancial disclosures by 11 organizations during a 3-year timespan to investigate how they responded to major scandals in terms of social, environmental and sustainability reporting and a content analysis of independent counter accounts to detect the presence of views that contrast with the corporate disclosure and suggest hypocritical behaviors.

Findings - Four patterns in the adaptation of reporting - genuine, allusive, evasive, indifferent - emerge from information collected on scandals and socially responsible actions. The type of scandal and cultural factors can influence the response to a scandal, as environmental and social scandal can attract more scrutiny than financial scandals. Companies exposed to environmental and social scandals are more likely to disclose information about the scandal and receive more coverage by external parties in the form of counter accounts. Originality/value - Using a theoretical framework based on legitimacy theory and organizational hypocrisy, the present research contributes to the investigation of the adaptation of reporting when a scandal occurs and during its aftermath.
\end{abstract}

Keywords Nonfinancial disclosure, Corporate scandal, Content analysis, Corporate social responsibility, Hypocrisy, Legitimacy theory

Paper type Research paper

(C) Marco Bellucci, Diletta Acuti, Lorenzo Simoni and Giacomo Manetti. Published by Emerald Publishing Limited. This article is published under the Creative Commons Attribution (CC BY 4.0) licence. Anyone may reproduce, distribute, translate and create derivative works of this article (for both commercial and non-commercial purposes), subject to full attribution to the original publication and authors. The full terms of this licence may be seen at http://creativecommons.org/licences/by/4.0/legalcode

We sincerely thank Lee Parker and the two anonymous referees for their helpful comments during the review process. An early version of this study was presented at a seminar at the Free University of BozenBolzano and we are thankful for the feedback received from the attendants.

Although this study is the result of a team effort, Marco Bellucci can be considered the author of Sections 3.2, 4 and 5; Diletta Acuti is the author of Sections 2, 3.1 and 5; Lorenzo Simoni is the author of Sections 3.1, 3.2 and 4; and Giacomo Manetti is the author of Sections 1 and 2.

Declarations of interest: None.

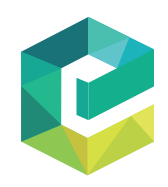

Received 23 December 2019

Revised 28 June 2020

20 January 2021

28 April 2021

Accepted 6 July 2021

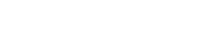


AAAJ

34,9

196

\section{Introduction}

In the past two decades, nonfinancial disclosure has become widespread with the increasing popularity of corporate social responsibility (CSR) in both research and practice (Aguinis and Glavas, 2012). However, an enduring wave of corporate scandals and disasters - including the recent Facebook-Cambridge Analytica data privacy scandal at Facebook, the emissions scandal and experiments on humans at Volkswagen, and the dramatic Boeing 737 Max plane crashes - has threatened the legitimacy of many corporations and other large organizations (Lin-Hi and Muller, 2013; Zyglidopoulos, 2001).

Research on crisis communication has addressed reputational damage caused by a scandal (Benoit, 1995, 1997), initially focusing on the communication - message, tone and strategy - of the crisis manager and then shifting to a receiver orientation, examining reactions of people interested in or affected by the crisis (Coombs and Holladay, 2014; Lauwo et al., 2019; McDonald et al., 2010; Adams and Zutshi, 2014; Kuruppu and Milne, 2010). According to Dean (2004), companies can lose their social legitimacy if they are perceived as irresponsible, dishonest, breaking the law or acting in a manner that exhibits little concern for society. When a "legitimacy gap" - the discrepancy between business behaviors and societal expectations (Sethi, 1977) - is too wide, the organization's survival is threatened. To limit their loss of legitimacy, organizations must reestablish congruency between the values implied by their actions and accepted societal norms through, among other actions, developing an appropriate communication strategy (Cho et al., 2012; Lindblom, 2010).

Critical literature stresses that social, environmental and sustainability (SES) reports and other nonfinancial disclosures may serve as veils that hide an organization's intent to strategically reconstruct its eroding legitimacy (Deegan, 2002). Indeed, parts of the social and environmental accounting literature have addressed how nonfinancial reports hide opportunistic strategies and the legitimizing efforts of managers among internal and external stakeholders (Bebbington, 2001; Bellucci et al., 2019; Deegan, 2002; Dumay et al., 2018; Milne and Patten, 2002). Conspicuous CSR communication is often associated either with organizations attempting to defend their corporate legitimacy or companies that have experienced a legitimacy issue (Bini et al., 2016; Morning and Schultz, 2006), under the principle that "the more problematic the legitimacy, the greater the protestation of legitimacy” (Ashforth and Gibbs, 1990, p. 185).

Much of the literature acknowledges the importance of exploring the effects of various factors on the perception of account appropriateness (Schmitt et al., 2004). Both impression management theory (Neu et al., 1998) and account episodes theory (Schönbach, 1990) identify five relevant components for making the communications strategies of scandal-ridden companies appear sincere, convincing and effective: (1) admitting fault, (2) admitting damage, (3) expressing remorse, (4) asking for forgiveness and (5) offering compensation.

Research suggests that the more companies expose their ethical and social ambitions, the more likely they are to attract criticism from their stakeholders (Ashforth and Gibbs, 1990; Morning and Schultz, 2006; Winkler et al., 2019). In other words, if an organization focuses too intently on communicating CSR virtues, some stakeholders may believe that the organization is trying to hide something (Brown and Dacin, 1997).

The promotion of desirable qualities such as CSR tends to evoke even more skepticism when a company already has a bad reputation or if it is in the midst of a significant scandal (Morning and Schultz, 2006). This aspect is why we decided to study the features of nonfinancial disclosure in eleven organizations that have weathered some of the largest environmental, organizational and financial scandals of the past twenty years. This approach allows us to investigate the topics of corporate hypocrisy and legitimacy. More specifically, the present study contributes to the scientific debate on hypocrite in SES reporting by empirically analyzing, through a diachronic approach, how organizations adapt their nonfinancial disclosure after a scandal. In the companion paper to this study, stakeholders' 
perceptions in terms of legitimacy and hypocrisy related to different reporting behaviors are experimentally tested. Such information is particularly interesting for legitimacy theorists for two main reasons. First, as suggested by several authors, the literature lacks diachronic studies after a corporate scandal, which represents an event in a company's life that can deeply undermine the credibility and the identity of such entities in the eyes of the stakeholders (Bebbington et al., 2008; Blanc et al., 2019). Second, a scandal can provide an evocative interpretation of the concepts of organizational hypocrisy and façade that can help the organization in balancing divergent stakeholder claims, thus identifying new ways to survive and plan a restart.

Our article is structured as follows. The next section presents our theoretical framework based on organizational hypocrisy, legitimacy theory and Benoit's (1995) classification of the most recurrent behaviors adopted by companies involved in a scandal. Section 3 illustrates the methodology of our diachronic content analysis of nonfinancial disclosures and counter accounts. Section 4 presents our findings on the patterns of the evolution of nonfinancial disclosure after a legitimacy-eroding event, also in light of a comparison with third-party counter accounts. Section 5 summarizes and discusses the main contributions and managerial implications of our study and provides ideas for further research.

The results of the present article have informed a second study that empirically tests the perceptions of report users after a corporate scandal. This latter study focuses on the concepts of remedial actions pursued by companies and admission of fault and is presented in a separate companion paper in this issue.

\section{Theoretical framework}

Hypocrisy has been defined as a gap between assertions and actions (Shklar, 1984) and refers to the "motivation to appear moral yet, if possible, avoid the cost of actually being moral" (Batson et al., 2006, p. 321). Typically, hypocrisy is seen as undesirable and something to be called out and eradicated (Delmas and Burbano, 2011), but some authors have explored its inevitability (Brunsson, 2002) and even its desirability (Cho et al., 2015; Christensen et al., 2013). In complex societies, corporations face diverse and often irreconcilable expectations, and structured hypocrisy can help reconcile divergent interests from diverse stakeholder groups. In this regard, Brunsson's model of organized hypocrisy $(1990,1993,2002,2007)$ and related studies (e.g. Christensen et al., 2013; Cho et al., 2015) define organized hypocrisy as an attempt to explain the discrepancies between an organization's image, planning and concrete actions and how these discrepancies may offer organizations flexibility in managing conflicting stakeholder expectations. Brunsson, in particular, goes beyond a model of a unitary corporate façade, showing the ideas of reputation and organized hypocrisy that can act as organizational and managerial purposes beyond societal legitimacy. Cho et al. (2015) apply the concepts of organizational façade and organized hypocrisy to sustainability reporting. These two notions, in fact, when taken together, raise the possibility that incongruence between a corporation's talk and its actions may generate beneficial consequences for a broad set of organizational stakeholders. According to Brunsson (2007), especially in the context of corporations, hypocrisy hides opportunities for change and can help sustain the societal legitimacy of organizations. Christensen et al. (2013, p. 385) affirm the following: "The tricky issue here, of course, is whether the motive behind hypocrisy is to conceal an unpleasant truth or to reduce the difference between current and aspirational reality."

Moreover, Glozer and Morsing (2020, p. 365) assert that "conventional definitions of corporate hypocrisy emphasize its basic criterion as a systematic decoupling between talk and action." In other words, hypocrisy is "the belief that a firm claims to be something that it is not" (Wagner et al., 2009, p. 79). These definitions of hypocrisy are adopted in this study.
Restoring an eroded legitimacy 
AAAJ

34,9

198

However, the concept of hypocrisy must be read in the light of companies' legitimacy issues, which are crucial to their survival and success since the community and society at large are seen as increasingly important stakeholders (Mitchell et al., 1997). As corporate entities are influenced by and often influence the society in which they operate, societal aims and perceptions can influence their policies. Thus, legitimacy can be viewed as a generalized perception or assumption that the actions of an entity are desirable, proper or appropriate within a socially constructed system of norms, values, beliefs and definitions (Suchman, 1995). This definition implies that legitimacy is a desirable social good, that it is something more than a matter of optics and that it may be defined and negotiated at various levels of society (Mitchell et al., 1997). Organizations are thought to be legitimate when they pursue socially acceptable goals in a socially acceptable manner.

As Buhr (1998) suggests, there are two dimensions at play in an organization's efforts to attain legitimacy: action (whether the organization's activities are congruent with social values) and presentation (whether the activities appear to be congruent with social values). Of course, the actions of an organization may deviate extensively from societal norms, but because the divergence goes unnoticed, the organization retains its legitimacy (Chen and Roberts, 2010).

Legitimacy is also a dynamic concept, as expectations can change over time and particular events might occur that adversely affect the reputation of a company, its legitimacy and perhaps even its very existence (Makela and Nasi, 2010). Such change is often considered a resource among supporters of legitimacy theory. On the one hand, organizations are dependent on this resource for survival (Dowling and Pfeffer, 1975); on the other hand, organizations can manipulate how society perceives their behavior and activities: managers will pursue strategies to ensure the continued supply of resources whenever the supply of that particular resource is deemed vital to organizational survival (Deegan, 2002). Kuruppu et al. (2019, p. 2081) have highlighted how legitimating actions relate to subtle, direct and episodic interventions to placate specific salient stakeholders; for these authors, response behavior is modulated by the need to gain, maintain or repair legitimacy, especially recurring to intimate interactions with close stakeholders to preserve "good character" and secure the company's license to operate in a particular locality. As suggested by Bebbington et al. (2008), this sporadic interaction is coherent with the fact that reputation risk management could assist in understanding SES reporting practices and that stakeholder dialogue can be used as a mere legitimating tool (Adams, 2004, p. 733).

The tension between sustainability discourse and practice has generated extensive and in-depth studies on corporate voluntary sustainability reporting, often resulting in contradictory conclusions (Milne and Gray, 2013; Unerman and Chapman, 2014). While some authors support the potential of SES reporting to make corporations more accountable and transparent about their social and environmental impacts (Bebbington et al., 2014; Rodríguez and LeMaster, 2007), part of the literature calls into question the validity of this accounting practice because it tends to be limited in scope (O'Dwyer et al., 2005), disingenuous (Aras and Crowther, 2009) and utilized as a legitimacy tool (Cho et al., 2012; Magness, 2006; Milne and Gray, 2007) or for responding to institutional pressures (Thorne et al., 2014). Supporters of legitimacy theory maintain that companies engage in SES reporting mainly to secure their own interests (Milne and Gray, 2013) with the explicit aim of deflecting, obfuscating or rationalizing their relatively poor social and environmental performance under reputational threats (Cho et al., 2010, 2015), rather than indicating rational plans and actions for facing real sustainability problems (Boiral, 2013; Cho et al., 2010; Patten, 2012).

Given the above, we can affirm that legitimacy theory has contributed to accounting theory in several ways over the past forty years, especially in the field of SES accounting and reporting. For example, legitimacy theory is often used to motivate CSR and voluntary nonfinancial disclosures. From this perspective, organizations issue SES reports to reduce 
their external costs or diminish pressures that are being imposed by external stakeholders or regulators (Adams, 2002; Tate et al., 2010). This behavior occurs because organizations use these reports to influence (or even manipulate) stakeholder perceptions of their image, performance and impact (Coupland, 2006; Deegan, 2002; Guidry and Patten, 2010). This assertion seems to question the validity of legitimacy theory in stimulating the production of reliable and useful SES reports. Scholars who support this theoretical perspective claim that legitimacy problems can emerge (Deegan, 2002; Patten, 1992) when there is a disparity between community values and the organization's values and impacts. The loss of consensus can be extremely dangerous for companies, especially in terms of successful customer acquisition and long-term retention; thus, by using external accountability mechanisms, sustainability disclosure can strengthen an organization's social legitimacy and improve its image and perception among external stakeholders and the local community, which is sometimes referred to as green washing (Clarkson et al., 2011).

The manipulation of an organization's image is perceived as being easier to accomplish than improving sustainability performance, supply chain structure or value system (Dowling and Pfeffer, 1975; Szabo and Webster, 2020). A conscious or unconscious manipulation approach is fairly common among firms (especially the biggest ones) that have negative social or environmental impacts, even referring to dialogic tools of communication such as social media (Lee et al., 2018; Manetti and Bellucci, 2016). For these reasons, legitimacy theory applied to SES reporting is intertwined with stakeholder skepticism within the CSR domain, increasing the idea of corporate hypocrisy, especially by consumers and local communities (e.g. Torelli et al., 2012; Wagner et al., 2009). SES reporting can be used as a means of demonstrating that the organization has realigned its practices, policies and performance with the expectations of organizational audiences. The analysis focuses on the strategies used in corporate narrative documents to restore legitimacy after a corporate scandal, environmental disaster or product failure.

Following previous studies (Bebbington et al., 2008; Lauwo et al., 2019), in this paper, we build on the framework developed by Benoit $(1995,1997)$ to identify the most recurrent behaviors adopted by companies that have been involved in a scandal. Benoit (1995) sustains that, in an attempt to mitigate the effects of the scandal, companies might explain the actions that have been put into place but might also be evasive and focus on other aspects of their operations that reflect positively on corporate behavior. These diverse behaviors present interesting relationships with the concept of hypocrisy, understood as the discrepancy between claims and the actions pursued and with the concept of legitimacy as forms of social accreditation.

More specifically, Benoit (1995) suggests that a company can deny or be silent about the triggering event or disclose information about what has happened. From these implications, Benoit derives an interest in the scope and extent of voluntary disclosure on salient information regarding a corporate scandal: the choice to disclose or not disclose information about what happened can depend on several circumstances. If a company is not exposed to the scrutiny of a wide range of stakeholders, the decision to avoid disclosure can serve the purpose of avoiding attracting unwanted scrutiny (O'Donovan, 2002; Kuruppu et al., 2019). If a company is exposed to intense scrutiny, stakeholders will expect it to be accountable and admit its fault for what occurred; in this latter case, external reporting serves the purpose of achieving moral legitimacy (Kuruppu et al., 2019), thereby legitimizing the company's actions in the eyes of stakeholders on the basis of societal moral norms (Suchman, 1995).

The present study can advance the current literature on this topic by examining the instrumental use of corporate reporting by empirically analyzing how organizations adapt their SES reports after a scandal and the nature of stakeholder perceptions of legitimacy and hypocrisy.
Restoring an eroded legitimacy 


\section{AAAJ}

34,9

200

\section{Methodology}

\subsection{Coding framework}

We explored the instrumental use of corporate reporting by empirically analyzing how organizations adapt their SES reports after a scandal. For this purpose, we used content analysis of company reports (Bryman and Bell, 2015). The same methodology was applied to the investigation of counter accounts produced by independent parties (Brown et al., 2015; Gallhofer et al., 2015) in the same periods.

Content analysis is a research technique that objectively and systematically identifies specific characteristics of certain types of information (Holsti, 1969). It offers a flexible approach to the examination of various media, documents and texts while also quantifying content according to predetermined categories in a systematic and replicable manner (Bryman and Bell, 2015). It has long been used in corporate disclosure studies (Guthrie et al., 2004; Manetti and Bellucci, 2016), because it encourages repeatability and valid inferences from data (Krippendorff, 2004). Content analysis can be used to better understand the meanings, intentions, consequences and context of communication (Cavanagh, 1997) and identify critical processes (Lederman, 1991).

We used the results of the content analysis (i.e. the two major dimensions that distinguish nonfinancial disclosure) as a point of departure to further explore stakeholders' perceptions (i.e. legitimacy and hypocrisy) in the companion paper to this article. Taken together, the two studies offer a more complete picture of the phenomenon under study and produce robust findings (Davis et al., 2011). Indeed, by collecting and combining the strengths of both qualitative and quantitative data, we provide a better answer to the research questions (Hoque et al., 2017). Although the weights assigned to the quantitative and qualitative components are equivalent, the qualitative study precedes the quantitative one.

We explored the main components that characterize the nonfinancial disclosure of companies involved in a scandal. Specifically, we observed how companies report and disclose their commitment to sustainability during a crisis and how corporate reporting practices changed following the scandal. Doing so enabled us to identify different clusters of organizational behaviors and the major dimensions that differentiate nonfinancial disclosure. Based on the evidence of this paper, in the companion study, we explored potential users' reactions to different nonfinancial disclosures.

Building on the purposive sampling design used in Romenti et al. (2014), we decided to use multiple cases as a means of assessing whether nonfinancial disclosure is used by organizations facing a financial, organizational or environmental crisis in order to regain legitimacy. We deliberately selected eleven cases - British Petroleum (BP), Deutsche Bank, Deutsche Post, FIFA, JP Morgan, Livestrong Foundation, Monsanto, Samarco, Tesco, Toshiba and Volkswagen - that fulfilled the following criteria:

(1) The organizations issued a nonfinancial disclosure or an integrated report during, one year before and one year after the crisis;

(2) The sample exemplifies different crisis types and levels of responsibility;

(3) The crisis drew international media attention;

(4) The crisis resulted in significant compensation and/or reparations (e.g. class action lawsuits);

(5) The events happened after 2006, the year of publication of the widely adopted Global Reporting Initiative G3 reporting guidelines.

Table 1 illustrates the various features of our sample. 


\begin{tabular}{|c|c|c|c|c|c|c|}
\hline Organization & $\begin{array}{l}\text { Year of } \\
\text { scandal }\end{array}$ & Scandal & Type of crisis & Sector & $\begin{array}{l}\text { Country of the } \\
\text { organization }\end{array}$ & $\begin{array}{r}\text { Restoring an } \\
\text { eroded }\end{array}$ \\
\hline $\mathrm{BP}$ & 2010 & Oil disaster & Environmental & Oil and Gas & England & \\
\hline Deutsche Bank & 2013 & Corruption & Financial & Bank & Germany & \\
\hline Deutsche Post & 2008 & Tax evasion & Financial & Post & Germany & \\
\hline FIFA & 2015 & Corruption & $\begin{array}{l}\text { Socio- } \\
\text { organizational }\end{array}$ & Sport & Switzerland & 201 \\
\hline JP Morgan & 2013 & $\begin{array}{l}\text { Improper } \\
\text { accounting }\end{array}$ & Financial & Bank & USA & \\
\hline $\begin{array}{l}\text { Livestrong } \\
\text { Foundation }\end{array}$ & 2012 & $\begin{array}{l}\text { Founder accused } \\
\text { of doping }\end{array}$ & $\begin{array}{l}\text { Socio- } \\
\text { organizational }\end{array}$ & Charity & USA & \\
\hline Monsanto & 2011 & $\begin{array}{l}\text { Improper } \\
\text { accounting }\end{array}$ & Financial & Agriculture & USA & \\
\hline Samarco & 2015 & $\begin{array}{l}\text { Mining dam } \\
\text { collapse }\end{array}$ & Environmental & Mining & Brazil & \\
\hline Tesco & 2014 & $\begin{array}{l}\text { Accounting } \\
\text { scandal }\end{array}$ & Financial & Retailer & UK & $\begin{array}{r}\text { Table } 1 . \\
\text { izations whose }\end{array}$ \\
\hline Toshiba & 2015 & $\begin{array}{l}\text { Accounting } \\
\text { scandal }\end{array}$ & Financial & Electronics & Japan & $\begin{array}{r}\text { non-financial } \\
\text { disclosure was }\end{array}$ \\
\hline Volkswagen & 2015 & $\begin{array}{l}\text { Emissions } \\
\text { scandal }\end{array}$ & $\begin{array}{l}\text { Socio- } \\
\text { organizational }\end{array}$ & Automotive & Germany & $\begin{array}{r}\text { subjected to content } \\
\text { analysis }\end{array}$ \\
\hline
\end{tabular}

Using categories provided by Coombs (2007), our study focuses on several different types of crises, including natural disasters, organizational misdeeds, management misconduct, corruption, human-error accidents and technical-error accidents. Stressing different organizations and crisis types allows us to explore how companies decided to address challenges to their legitimacy while also commenting on responsibility levels and the nature of these crises.

We collected information that could help us understand how companies report and disclose their commitment to sustainability during a crisis. We focused on SES reports from the year before the scandal as a baseline and proceeded to analyze reports in the next two years in order to understand the evolution of disclosure following a crisis. If an SES report was not available in a specific year, we selected the most similar piece of nonfinancial disclosure or the complete annual report.

To investigate how corporate reporting practices changed following the scandal, we developed an analytic framework based on a preliminary study of the scholarly literature (Hildebrand et al., 2017; Schultz et al., 2011) and the results of a pilot study where three expert researchers independently ran a content analysis on the SES reports of BP for the years 2009, 2010, 2011 and 2012 using a preliminary set of categories. The results of this pilot study were discussed, and a final set of categories was then defined. The categories used in our main content analysis are shown in Table 2 . We collected data about the general features of the report, the basic features of the scandal and how it was managed, relevant stakeholders and the communication strategies that were adopted in its wake.

Prior research emphasizes that corporate communication usually offers a partial representation of the facts described, mainly based on management perceptions (Adams, 2004; Milne et al., 2009). A solution to this issue is represented by the use of alternative representations of the facts produced by other parties, which can be affected by a company's activities. These sources of information have the capability of complementing official disclosures by problematizing and challenging the facts presented by a company in its official statements (Adams, 2004; Dey et al., 2011; Ruffing, 2007; Tregidga et al., 2012), thereby giving voice to a greater range of interested parties (Brown et al., 2015; Gallhofer et al., 2015). 


\section{AAAJ 34,9}

\section{2}

Table 2.

Items analyzed in content of reports

\section{Categories \\ Description}

General info

Reference to the scandal

Reference in the summary

Quantification of the damage

CSR remedy

Images of the scandal Preston et al. (1996), Busco and Quattrone (2015)

Channel of stakeholder engagement

Engaged stakeholders

Degree of stakeholder engagement

Stakeholder comments

Communications strategy Schultz et al.

(2011)

Admission of fault Linsley and Kajuter

(2008), Schultz et al. (2011)
Title, typology and year of publication of the report

Presence of any reference to or descriptions of the scandal in the report

Whether there is a reference to the scandal in the general summary of the report

Disclosure about the costs associated with the consequence of a scandal

Presence of descriptions of actions aimed at finding solutions for the crisis and an assessment of whether these solutions were coherent

Presence and assessment of any images related to the scandal

Description of active channels of stakeholder engagement Description of the categories of engaged stakeholders Level of stakeholder engagement

Disclosure of comments made by involved stakeholders

Type of communication strategy

Presence of any explicit admission of guilt by the company

The main source of alternative representation is counter accounting (Gallhofer et al, 2006). This term is used to refer to documents on a company's activity produced by different kinds of external parties and usually spread on the web, which represents a freely accessible space that stakeholders are increasingly using to collect information on a company (Gallhofer et al., 2006). Stakeholders that issue counter accounts can recognize and confirm a company's engagement with CSR and offer additional information about its activities. Additional information provided through counter accounts can either be supportive of a company's claims or express contrasting views (Hooghiemstra, 2000; Joutsenvirta, 2011; Laine and Vinnari, 2017).

For these reasons, we integrated the content analysis of SES reports through an analysis of counter accounts, allowing us to reconstruct a more complete picture of companies' CSR activities.

Some studies use counter accounts to assess the presence of contrasting views expressed by some groups of stakeholders (e.g. Laine and Vinnari, 2017). To the aim of this study, we consider information on CSR issued from independent sources to better understand a company's activities in relation to a crisis.

While some empirical studies on counter accounting focus on documents produced by specialized NGOs (e.g. Denedo et al., 2017), others consider news articles produced by any external group (Boiral, 2013). In this study, we adopt the same definition as Boiral (2013). News articles included in the study must address one of the scandals under investigation and its consequences and must be based on specific documented facts (Boiral, 2013). Our main information source was the EBSCO Business Source Premier databank. Overall, we found 107 reports with the abovementioned characteristics. The reports were carefully read by two expert researchers. This allowed us to analyze documents produced by different stakeholder groups associated with the companies in our study.

\subsection{Hypocrisy in corporate reports}

We focused on SES reports and categorized the different behaviors of the organizations in our sample concerning the disclosure of nonfinancial information after an environmental, 
socio-organizational or financial scandal. As declared in our theoretical framework, we build on the framework developed by Benoit $(1995,1997)$ to identify the most recurrent behaviors adopted by companies that have been involved in a scandal. The first issue that we consider is whether a company decides to disclose information about a scandal. According to Benoit $(1995,1997)$, a firm might decide to remain silent about a critical event to not attract unwanted scrutiny. In the presence of a scandal, this decision is also influenced by the salience of the event and, ultimately, by the type and magnitude of the scandal. We label this dimension the scope of disclosure on the scandal.

As highlighted in Section 2, SES reporting plays a crucial role during organizational crises or public controversies as a means of resolving the conflict by shaping audiences' attitudes toward the issue of contention. The literature suggests that the use of rhetoric and argument is particularly frequent during public controversies, conflicts over values or shortfalls in corporate social and environmental performance (Brennan and Merkl-Davies, 2014; Coupland, 2006) since organizations depend on public approval and need to build public trust.

As all companies under investigation have been involved in significant scandals, which have seriously harmed the organizations themselves and the environments they operate in, we consider a company that decides to disclose information according to the response strategies identified by Benoit as an "evasion of responsibility" and as "reducing the offensiveness of an event" as potentially hypocritical. Evading responsibility involves attributing fault to circumstances or accidents, while a reduction of offensiveness takes place by providing information about other aspects that are positive or by minimizing the magnitude of the event. An evasion of responsibility and attempts to reduce the offensiveness of an event might reveal potential hypocritical behaviors. Hence, disclosure itself cannot offer a coherent account of how a company has managed a crisis.

To better understand the coherence between information disclosed and actions effectively taken, we have collected information on the disclosure of remedial actions. Benoit (1997) refers to the communication of this kind of information as the disclosure of "corrective actions." The disclosure of corrective actions is considered fundamental to achieving moral legitimacy when a scandal occurs (Kuruppu et al., 2019). Hence, the second aspect relates to the extent to which a company offers information on the actions taken after a scandal. We label this dimension as the scope of the disclosure of remedial actions.

The dimensions analyzed allowed us to build a Cartesian system for companies' classification (Figure 1), where the scope of the disclosure of scandals and related factors is on the $x$-axis and the scope of the disclosure of remedial actions is on the $y$-axis. The following elements in the reports contributed to the categorization: (1) extensive accounts of the scandal in the main text of the report; (2) reference to the scandal in the general summary of the report; (3) disclosure about the costs associated with the consequences of the scandal; (4) explanations of coherent actions aimed at finding remedial solutions for the crisis or providing relief to the affected stakeholders; and (5) images directly related to the scandal; (6) clear admission of fault or responsibility.

This classification permits the identification of potential hypocritical behaviors based on our theoretical framework. Companies positioned in the second quadrant (no disclosure about the scandal, but description of remedial actions) and in the fourth quadrant (disclosure of the scandal, but no illustration of actions or strategies that allow to restore a company's image) can be labeled as potential hypocrites. In fact, a difference between claims and actions would emerge in the former case (a company that speaks about remedial actions but does not admit fault and does not refer to the scandal), while in the latter case, a company might want to appear moral by disclosing information about the scandal but not bearing the costs related to the remedial actions needed (Batson et al., 2006), reflecting a decoupling between talk and action (Glozer and Morsing, 2020; Wagner et al., 2009). However, companies in the first quadrant (full disclosure of the scandal and the related remedial actions) may also be
Restoring an eroded legitimacy 

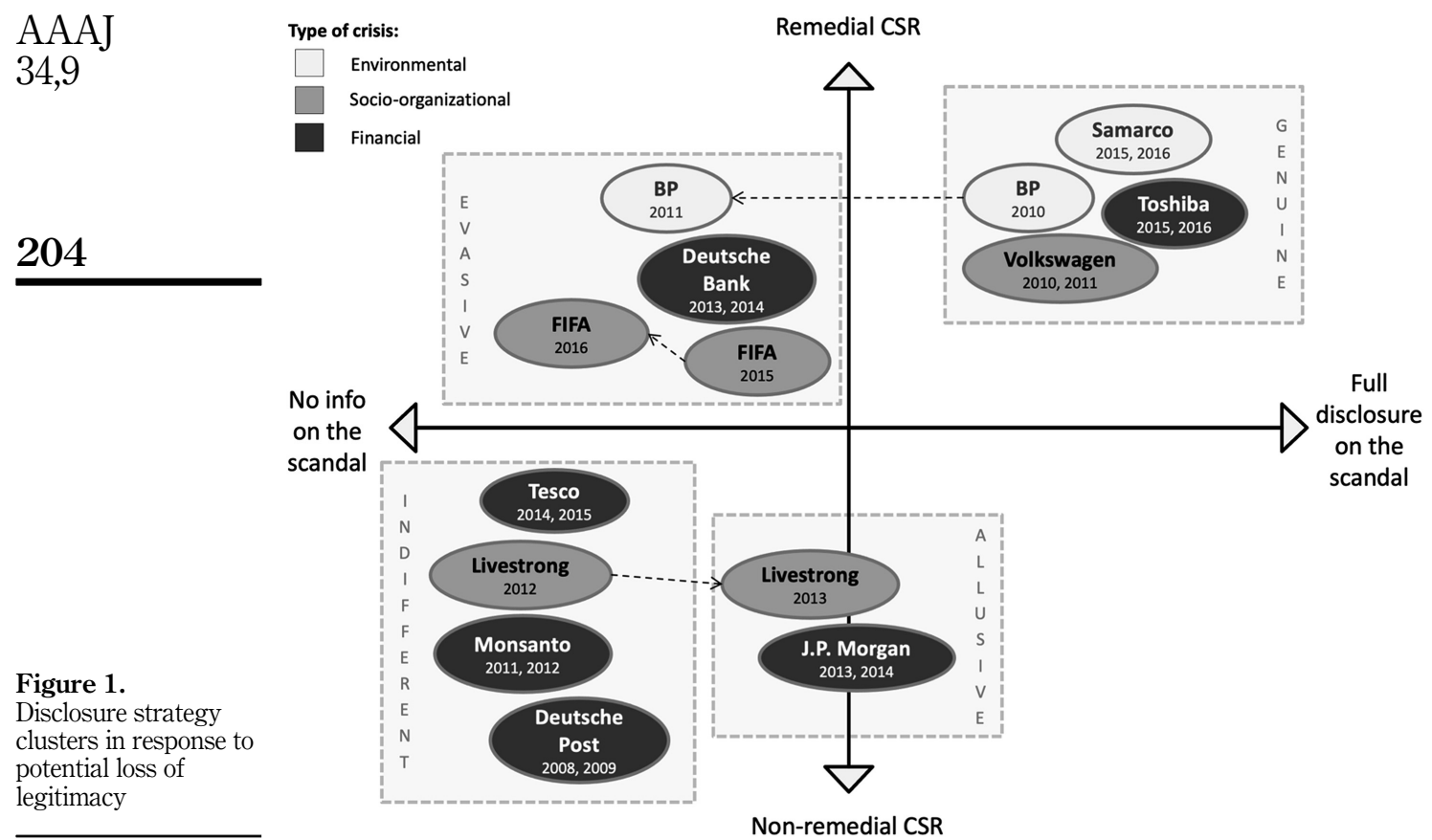

Figure 1.

Disclosure strategy clusters in response to potential loss of legitimacy

considered hypocritical if the actions depicted are not coherently implemented (Brunsson, 1989). In light of this, an investigation of counter accounts can support the detection of potential hypocrisy for organizations positioned in the first quadrant.

\section{Results: different patterns in nonfinancial disclosure after a scandal}

Figure 1 provides a graphical representation of the categorization that emerged from the content analysis, including the different clusters of organizational behaviors, and the diachronic effects between the first and second years of reporting after the scandal for certain organizations.

Four clusters of company behavior concerning nonfinancial disclosure after a potentially legitimacy-eroding scandal emerge. The following sections depict the characteristics of reporting for companies in each cluster.

\section{1 "Genuine" reporting practices}

The first cluster encompasses those organizations that, after a scandal, provided full disclosure of the events, an admission of fault and an illustration of the remedies taken, often with associated quantitative data and costs, such as BP does in its 2010 report:

The tragic accident in the Gulf of Mexico on 20 April 2010 cost 11 lives, leading to a major oil spill and a widespread loss of trust in BP. We are so very sorry for what happened. (...) Our task now is to earn back the trust that was lost and build a sustainable BP for the future. This report explains the measures we are taking to strengthen safety, restore trust and build shareholder value responsibly for the long term. 
The report also illustrates the efforts made to take remedies:

Restoring an eroded

Within hours of the Deepwater Horizon accident, BP teams were working to stop the leak. We also acted to minimize the spill's impact on the environment by containing, removing and dispersing oil offshore, protecting the shoreline and cleaning up oil that came ashore. And we worked with wildlife groups to develop rescue and rehabilitation programmes for turtles, birds and other species.

BP Sustainability report 2010

We label the group of organizations featuring this modality of nonfinancial disclosure, represented in the outer part of the first quadrant of the Cartesian system depicted in Figure 1, as the "genuine" cluster. Organizations in this cluster appeared to provide full and transparent disclosure of the negative events, and many of their resulting CSR practices were coherent with the issues at the center of the scandal. The following excerpt illustrates the expression of regret and the willingness to put remedial actions in place by Volkswagen:

When it comes to the diesel crisis, we have failed to live up to our own standards in several areas. The irregularities in the handling of emissions tests contradict everything that we stand for. We regret this immensely and are aware that we have let our stakeholders down. We (. . .) are fully committed to re-embracing our standards and winning back public trust.

Our approach, Volkswagen 2016 Sustainability report, p. 7

Among the companies that were protagonists of financial scandals, Toshiba, one of the major Japanese-based multinationals, was the only one that reported on the incident and the remedies put in place. Their report dedicated many paragraphs to the matter and provided a detailed public apology. This could reflect a cultural, country-based influence.

The 2015 and 2016 reports from Samarco, 2015 and 2016 reports from Toshiba, 2015 and 2016 reports from Volkswagen and a 2010 report from BP provided all of these details. At least to an investigation that does not include external points of view, these reports did not attempt to hide any sensible information about the scandal or the company's responsibilities.

The content analysis of independently issued news articles revealed that, in most cases, counter accounts explicitly supported companies' actions and integrated the set of information that can be found in SES reports. Starting from the "genuine" cluster, we observe that counter accounts seemed to confirm the actions that Volkswagen, Toshiba and Samarco adopted as remedies. An example is provided as follows (Toshiba):

The electronics to nuclear power conglomerate has since appointed more outside directors and has set about restructuring its business, including selling off unprofitable divisions.

Why Toshiba Is Getting Hit With A Record Fine, Fortune

Some misalignments between what the companies declared and the actions they undertook emerged from the analysis of counter accounts regarding BP. In fact, some documents supported the view that BP behaved hypocritically. Soon before the scandal, the company claimed to be the greenest oil and gas company (Mark Ritson, "Rebranding cannot plug credibility gap," May 2010). Moreover, the BP 2009 sustainability report noted that safety and employee training represented key aspects of BP's operating style. Some articles criticized BP because the disaster could have been avoided. One report reads as follows:

On Tuesday, the National Commission on the BP Deepwater Horizon Oil Spill and Offshore Drilling, established by President Barack Obama last May, released its final report. The commission concluded that the blowout, which eventually caused more than 4 million barrels of oil to flow into the Gulf of Mexico, was preventable and the result of a "systemic" industry-wide failure to put safety first. 
AAAJ 34,9

\section{6}

Another issue reported that $\mathrm{BP}$ employees had not been properly trained. As a consequence, they were not able to detect the signals of the inadequacy of the cement that was used:

While unable to explain the pressure in the drill line, the well site leaders feel that the kill line results demonstrate the integrity of the bottom cement, and they declare the test a success. In fact, the test was no such thing, and the flow and pressure readings should have indicated to the crew that the cement was inadequate and that hydrocarbons were leaking into the well. Just a few hours later, emergency measures fail and hydrocarbons rising from the well ignite on the rig.

Tara Hoke, "Fostering a Culture of Safety," Civil Engineering, January 2013, p. 38

Other counter accounts claimed that BP was not doing as much as it could to remedy the crisis ("LEADER: Toxic BP must stop spreading its poison," Marketing Week, Vol. 33, Issue 25, June 2010). However, these counter accounts do not directly challenge remedial actions put in place by BP after the scandal but, rather, document inappropriate behaviors that previously occurred. The only exception is a document that claims that the company had paid United States but not Mexican fishermen for the damage (Veronica Calderon, "Mexican fishermen file US lawsuit against BP for Gulf oil spill damages).

As is subsequently shown in this section, BP is the only company that changed quadrants over the years, moving from "genuine" in 2010 (the year of the scandal) to "evasive" in 2011. The presence of different sources that criticized BP's behavior and the scarcity of information about the scandal in the year after the oil spill may signal the presence of a potential misalignment of claims and actions. Overall, the counter accounts seemed to confirm the efforts made by "genuine" companies to restore their legitimacy. Thus, companies in the "genuine" cluster do not show signs of hypocritical behavior.

\subsection{The "indifferent" cluster}

The opposite side of the Cartesian system, in the outer part of the third quadrant, includes organizations in the "indifferent" cluster. The reports of these organizations did not provide any coverage of the events of the scandal. Tesco (2014 and 2015 reports), Livestrong (2012), Monsanto (2011 and 2012) and Deutsche Post (2008 and 2009) opted not to include any disclosures about the scandal in their nonfinancial reports, trying not to create any link between them and the events that generated the scandal. In providing no disclosure, they consequently provided no information about the remedies taken, if any. In other words, stakeholders and users of these reports could not learn anything about the crisis by reading these reports. Livestrong was named the Lance Armstrong Foundation until 2011, when the doping scandal that toppled its funder was reported. However, this name change was not mentioned or explained in the 2012 report, suggesting a kind of organizational façade aimed at managing stakeholders' expectations. Neither Tesco, Deutsche Post nor Monsanto described their scandals or provided information on the events. Tesco provided even fewer details on stakeholder engagement practices in its 2014 reports than in the baseline report before the scandal; this was also the case for Volkswagen and could suggest a strategy to deflect criticism. In reports issued by Monsanto after its crisis, there was no mention of the scandal, although a list of measures adopted in subsequent years was included, especially concerning the improvement of internal controls.

\section{3 "Allusive" cluster and its relationship with "evasive"}

In the same third quadrant, but in the inner part, are organizations included in what we call the "allusive" cluster. JP Morgan (2013 and 2014 reports) and Livestrong (2013) merely alluded to some events that could be linked to the crisis or the scandal, or they hinted at the scandal using "difficult months," "tough periods" and similar expressions. No full disclosure was provided in these reports, and there were no indications to understand whether their CSR 
activities were coherent with the origin of the scandal. These reports did not comment on the specific issue or provide particular details. JP Morgan made no clear reference to the incident, while it highlighted the measures adopted to strengthen internal controls, the founding principles that inspired the company and the initiatives to support local communities and a sustainable economy.

Then, the third quadrant is characterized by the presence of two kinds of companies: "indifferent" (Tesco, Monsanto and Deutsche Post) and "allusive" (JP Morgan). Livestrong moved from "indifferent" during the year of the scandal to "allusive" during the following year. We could not find any independent report for Monsanto or Deutsche Post. Only one report was available for Tesco. The article reported on the company's decision to hire external auditors and lawyers to shed light on profit misreporting. A few independent reports addressed the Livestrong and JP Morgan scandals. For Livestrong, counter accounts discussed how many companies had decided to stop sponsoring the foundation. Some articles claimed that, despite the scandal, the foundation was supporting important projects. For JP Morgan, the only issue discussed was the settlement that the company had to pay for. The presence of only a few counter accounts might reveal that those companies are less covered by the media and, hence, might not have been under scrutiny as were other companies analyzed, which could be the reason for nondisclosure: companies that might avoid attracting unwanted scrutiny by not providing information about the scandal through external reporting. Crucial factors that can explain this circumstance are type of scandal and dimension. Tesco, Monsanto, Deutsche Post and JP Morgan have been involved in financial scandals, which might be less salient than social or environmental scandals. Financial scandals might also affect fewer stakeholder categories, whereas a social and environmental scandal can impact local communities and attract the attention of several NGOs and other associations. Regarding size, the only company included in this quadrant that has not been involved in a financial scandal is Livestrong. Livestrong is not a for-profit organization and is considerably smaller than the other companies in the same quadrant. Hence, the Livestrong scandal might have directly affected a restricted number of stakeholders.

\section{4 "Evasive" companies}

Finally, the fourth type of behavior pertains to organizations in the "evasive" cluster, positioned in the inner part of the second quadrant. As previously illustrated, companies in this quadrant can be considered to be hypocritical, as there is a gap between claims and actions. These reports - Deutsche Bank (2013, 2014), FIFA $(2015,2016)$ and BP (2011) - did not always provide full disclosure of the scandal or the crisis, but they did provide a limited set of information. The disclosure was focused on the remedies taken to strengthen some regulations, to avoid future issues or to signal a commitment into a specific direction.

On 26 February 2016, Zurich hosted an extraordinary FIFA Congress that kick-started a transformational and much-needed governance overhaul after the most challenging times in the history of the institution. (...) With new management in place and a strong legal framework to cement the principles of good governance in the organisation, in 2016 FIFA took a first and crucial step toward getting back on track.

2016: A year to refocus FIFA, FIFA Governance Report 2016, p. 11.

In other words, it appears they were willing to redirect the attention of stakeholders and users from the scandal directly to the remedies undertaken to avoid similar issues in the future, in a strategy to limit the consequences in terms of the erosion of their legitimacy. The companies in this cluster shared some common elements in their reporting practices, including weak and between-the-lines references to the scandal, several references to the values on which the
Restoring an eroded legitimacy 
AAAJ

34,9

208 company was founded, and extensive documentation on antifraud, anticorruption and risk mitigation measures adopted in the years following the scandal.

Independent reports on FIFA and Deutsche Bank mainly talked about what happened and the consequences of the scandals. No counter accounts directly contested the remedy plans of these organizations. This result may be related to the types of scandals - these two cases are the only cases of corruption included in our study. The behavior of companies in this quadrant can be considered an attempt to shape stakeholders' perceptions by disclosing only positive information (O’Donovan, 2002).

\subsection{Clusters and different types of scandals}

Organizations that suffered an environmental scandal tend to be located in the upper righthand part of the Cartesian system, in the "genuine" cluster. These organizations usually provided more comprehensive disclosure than organizations that suffered a different type of crisis or scandal. This may be because environmental scandals usually have a larger impact on media - think of the explosion on the Deepwater Horizon oil platform, the consequent "black sea" of oil and all the pictures of endangered wildlife. It would be impossible, if not counterproductive in terms of the legitimacy gap (Lindblom, 2010; Sethi, 1977), to ignore or hide such events in corporate reports. In addition to being a reporting principle, transparency represents a superior communication strategy in these cases.

The diachronic perspective provided many insights into how the organizations of our cases showed different behaviors across a two-year timespan after the scandal (Tilling and Tilt, 2010). BP represents an interesting case: its 2010 report, the first one after the crisis in the Gulf of Mexico, included "negative" images of, for example, the burning Deepwater Horizon platform or the large part of the ocean covered in black oil. However, in the following year's report in 2011, such images disappear, and only "positive" ones, such as pictures of brandnew oil platforms or clean ecosystems, are found.

The dynamic analysis of stakeholder engagement practices is also significant. The stakeholder engagement activities reported by BP expanded in the year after the crisis but then returned to normal levels that following year. This hints at the company's desire to signal a commitment to the needs of stakeholders and their requests, especially in times of turmoil. Likewise, in 2015, FIFA provided a fair, if not full, depiction of the events behind its corruption scandal, although it did not fully admit to any direct responsibility. This lengthy description did not appear again in the 2016 report, which reflects behavior similar to the use of images in BP reports. Another interesting example of minimization is Livestrong, formerly the Lance Armstrong Foundation: after quietly changing its name in 2012, it was not until 2013 that the foundation stated that it was "able to weather a tough period and move to the next phase of [its] evolution" (Letter from the President, Livestrong Foundation 2013 Annual report, p. 2).

\section{Discussion and conclusions}

Following previous studies (Bebbington et al., 2008; Lauwo et al., 2019), in this study, we adopted the framework developed by Benoit $(1995,1997)$ to identify the most recurrent behaviors adopted by companies that have been involved in a scandal. More specifically, we attempted to understand the actions implemented by companies when responding to a scandal.

Supported by a theoretical framework based on legitimacy theory and organizational hypocrisy, we investigated 11 companies that were involved in major scandals to assess changes in sustainability reports after a crisis occurred. Because SES reports might not be sufficient to fully understand a company's activities in response to a scandal, counter 
accounts - reports issued by independent third parties - were used to complement SES report analysis. Informed by the qualitative insights of this research, we also developed a companion paper to this article in which we conducted an experiment to understand how stakeholders perceive companies' actions aimed at creating legitimacy and restoring their images. Together, these two papers have value for investigating the adaptation of SES reporting from the integrated perspective of both organizations and their stakeholders, contributing to the accounting and management literature by answering the call for more research on how a message from a company is perceived (Tregidga et al., 2012).

The present research provides several contributions to the current literature on these topics. First, this study contributes to the literature on how companies react to corporate scandals and how their reporting practices change after such episodes occur. The focus of analysis is on nonfinancial disclosure strategies used to restore legitimacy after a corporate scandal, when accounting and nonfinancial disclosures are mobilized to conceal the threats of stigma, manage the legitimacy gap (Sethi, 1977) and repair spoiled identity (Lauwo et al., 2019). Our findings show that companies respond to corporate scandals in very different ways. While some companies (the "genuine") implement remedial actions and disclose extensive information about the scandal, others (the "evasive") put some remedial actions in place but do not communicate detailed information about the issues they faced. Some of the examined companies (the "indifferent" and, to some extent, the "allusive") did not implement any remedial actions or disclose information about the scandal. Our analysis of the "indifferent" cluster provides new empirical evidence to the strand of research initiated by Menon et al. (1999) and Griffin et al. (1991) on the "no comments" kind of disclosure after a crisis (Benoit, 1995; Kuruppu et al., 2019).

Second, we extend the framework developed by Benoit $(1995,1997)$ to investigate organizational responses to a significant scandal. While the original framework has been designed to address responses occurring during a crisis, which can also be based on groundless accusations, we explore cases where companies are effectively responsible for a scandal that has received scant attention. Moreover, while Benoit $(1995,1997)$ illustrates potential disclosure strategies that can be adopted during a crisis, we build on this framework and on the emerging evidence from SES reports issued by companies to define a more detailed framework that can be used to investigate nonfinancial disclosures occurring after a major scandal has occurred.

Third, our results show that the type of scandal and, to some extent, cultural factors can affect how a company manages an incident. From a legitimacy theory perspective, our empirical results can contribute to the developing literature on SES reporting as a means of demonstrating a realignment of organizational practices, policies and performance with the expectations of stakeholders. Our findings show that CSR represents a double-edged sword with respect to legitimacy-threatening episode management: the four patterns highlighted in our study show different ways to deal with stakeholders and the associated risk of hypocritical behavior after a scandal. Different reactions can be linked not only to the different scandals but also to the characteristics of the groups of stakeholders that the company has to deal with. Given the sector of activity and the extent of the scandal, BP, Samarco and Volkswagen ("genuine" cluster) may have received greater pressure from their stakeholders. Not surprisingly, we have found a significant number of counter accounts precisely for these companies. Then, arguably, to respond to the pressure, those firms reacted by offering broader disclosures. However, if the stakeholder groups are limited or not pressing, the company can choose not to use reporting to discuss what happened because doing so would attract much more attention than that attention that the scandal attracted (Kuruppu et al., 2019). This strategy acknowledges the erosion of legitimacy as a socially constructed process, in which being portrayed by prominent actors as deviating from the norm is more important than the actual deviation (Breitinger and Bonardi, 2019). Through
Restoring an eroded legitimacy

209 
AAAJ 34,9 our study, we also contribute to the calls by Scott and Walsham (2005) and Bebbington et al. (2008), who claim that conducting a longitudinal examination of companies' reports would be instructive to understand how they respond to a scandal.

Fourth, we contribute to understanding of third parties' insights into the instrumental use of corporate reporting. News media, social movements and NGOs perform an important function of monitoring and challenging organizational behavior. It is interesting to note that there were no dissenting counter accounts for companies that provided full disclosure of a scandal and performed coherent CSR activities. This suggests that this pattern of behavior is less vulnerable to claims of corporate hypocrisy, especially for environmental scandals, which have a large impact on media and public opinion. The counter account analysis revealed that only in a few cases did independent parties offer contrasting views of a company's actions and claims. This suggests that reducing the scope of the disclosure is not the best tactic if an organization wants to avoid green-washing claims and to preserve its legitimacy among third parties. It appears that monitor organizations and independent third parties appreciate the willingness to offer full disclosure without omitting negative performance.

The present research also inspires a set of practical recommendations. We believe that our research reveals some significant practical and managerial implications on how managers should handle a reputational loss, regain trust and avoid perceptions of hypocrisy. Our findings demonstrate that fully disclosing a scandal, its consequences and the related remedial actions lead to recognition from independent parties. As the counter accounts analysis shows, in most cases, coherency and transparency are confirmed and supported by independent third parties. Thus, companies that make full disclosure of the scandal by admitting their fault and illustrating remedial actions are likely not perceived as hypocritical. Therefore, managers should provide a description of the scandals and the factors that contributed to determining it. Details about the actions undertaken to face the scandal should be illustrated as well. Our findings suggest to managers that stakeholders can appreciate disclosure that highlights failures or mistakes, especially for voluntary disclosures. In addition, the disclosure of negative information is coherent with sustainable reporting standards, such as GRI, which demand that companies disclose positive and negative information to provide an unbiased disclosure of their performance (Jahn and Brühl, 2019).

The present research also has some limitations that could be overcome in future research.

First, with regard to the research design, the content analysis was limited to SES reports in the years before, during, and after the scandal. Further studies could broaden the sample of organizations and the parameters of the content and could include other forms of dialogic communication, which is an increasingly recognized vector of stakeholder engagement. Academic studies are paying attention to less conventional forms of communication surrounding a scandal, such as press releases or social media marketing campaigns, which could be examined. A company's disclosure on digital platforms is particularly relevant, as these technological instruments have significantly influenced how we keep track of events. This fact makes disclosure on digital platforms extremely impactful because their content is easily accessible to many individuals and can last for years. Stakeholders who engage in digital dialogues with a company can contribute to the coconstruction of the corporate image that emerges before, during and after a scandal. This process of cocreation can amplify the effects of hypocrisy perceptions, strengthening the hypocritical image and compromised legitimacy of a company. Indeed, this helps create a negative collective memory - a socially generated common perception of an event - that survives many years after a scandal (GarcíaGavilanes et al., 2017). We, therefore, pose the following questions for further research: How do companies adapt the digital disclosure of nonfinancial information after a scandal? How does this process evolve on digital platforms? Is digital dialogue with stakeholders helpful or detrimental to the process of restoring an eroded legitimacy? How can the four 
clusters that we have identified be adapted to the digital context? Similarly, press releases can be used as an effective means to convey CSR information (Guthey and Morsing, 2014), even when the need to consider different stakeholder informative needs generates ambiguity in messaging (Eisenberg, 1984). How can companies use press releases to adapt their social and environmental communication and preserve their legitimacy after negative media coverage?

Second, in our study, we provide a framework that depicts companies' different disclosures after a scandal. However, to implement one of the four behaviors concerning nonfinancial disclosure, companies can adopt different communication strategies that may reinforce or reduce organizational legitimacy and hypocrisy perceptions. For instance, genuine companies can decide to implement informative communication (informing stakeholders about the crisis and the companies' actions) or a more responsive strategy (where the companies demonstrate to stakeholders how they integrate their suggestions and concerns into the company's activities). Companies could also implement an involving strategy by asking stakeholders to work together to address the issue and limit the damage (Morsing and Schultz, 2006). As hypocrisy involves a willingness to appear moral while avoiding the cost of actually being moral, a mere informative strategy should be perceived as more hypocritical than the other strategies. However, as it is also represented by a gap between assertions and actions, the adoption of responsive communication should entirely correspond to the implementation of actual initiatives. This sets the stage for the following further research questions: What kind of communication strategy helps generate nonhypocritical accounts? Which strategy enhances hypocrisy perceptions? Which strategy improves the legitimacy of companies during and after a scandal?

Third, a communication strategy can also involve the use of different visual elements within a report. Although this study explores the use of images with negative and positive valence, further research could explore other characteristics of visual element employment. For instance, companies can use fictional images or real pictures for aesthetic or informative reasons and can use specific colors to generate particular emotions in the reader. Thus, future research can seek to answer the following questions: How can visual elements emphasize organizational legitimacy? Which images can reduce the hypocrisy perceptions of stakeholders? Which images can arouse a sense of hypocrisy?

Finally, although this research focuses on the role of companies' communication strategies, we recognize the impact that the counter accounts' point of view can have on other stakeholders' perceptions. Indeed, depending on the counter accounts' reputation and credibility or their motivation to question a company, their claims can provoke different effects. For instance, if stakeholders do not attribute genuine motivations to the counter accounts' activity, they can paradoxically play into the hands of the guilty company or diminish its responsibility. Thus, is the presence of counter accounts consistently negative for companies experiencing a crisis? Is the image of counter accounts relevant to the hypocrisy inferences of companies? We encourage further research adopting counter accounts' perspectives in new experimental designs and observing how they affect stakeholders' reactions.

\section{References}

Adams, C.A. (2002), "Internal organisational factors influencing corporate social and ethical reporting: beyond current theorising", Accounting, Auditing \& Accountability Journal, Vol. 15 No. 2, pp. 223-250.

Adams, C.A. (2004), "The ethical, social and environmental reporting-performance portrayal gap", Accounting, Auditing \& Accountability Journal, Vol. 17 No. 5, pp. 731-757.

Adams, C. and Zutshi, A. (2004), "Corporate social responsibility: why business should act responsibly and be accountable", Australian Accounting Review, Vol. 14 No. 34, pp. 31-39.
Restoring an eroded legitimacy 
AAAJ 34,9

Aguinis, H. and Glavas, A. (2012), "What we know and don't know about corporate social responsibility: a review and research agenda", Journal of Management, Vol. 38 No. 4, pp. 932-968.

Aras, G. and Crowther, D. (2009), "Corporate sustainability reporting: a study in disingenuity?", Journal of Business Ethics, Vol. 87 No. 1, p. 279.

Ashforth, B.E. and Gibbs, B.W. (1990), "The double-edge of organizational legitimation”, Organization Science, Vol. 1 No. 2, pp. 177-194.

Batson, C.D., Collins, E. and Powell, A.A. (2006), "Doing business after the fall: the virtue of moral hypocrisy", Journal of Business Ethics, Vol. 66 No. 4, pp. 321-335.

Bebbington, J. (2001), "Sustainable development: a review of the international development, business and accounting literature", In Accounting Forum, Vol. 25 No. 2, pp. 128-157.

Bebbington, J., Larrinaga, C. and Moneva, J.M. (2008), “Corporate social reporting and reputation risk management”, Accounting, Auditing \& Accountability Journal, Vol. 21 No. 3, pp. 337-361.

Bebbington, J., Unerman, J. and O’Dwyer, B. (2014), Sustainability Accounting and Accountability, Routledge, Abingdon.

Bellucci, M., Simoni, L., Acuti, D. and Manetti, G. (2019), "Stakeholder engagement and dialogic accounting: empirical evidence in sustainability reporting", Accounting, Auditing \& Accountability Journal, Vol. 32 No. 5, pp. 1467-1499.

Benoit, W.L. (1995), Accounts, Excuses, and Apologies: A Theory of Image Restoration Strategies, Suny Series in Speech Communication, State University of New York Press, Albany, pp. 244-261.

Benoit, W.L. (1997), "Image repair discourse and crisis communications", Public Relations Review, Vol. 23 No. 2, pp. 177-186.

Bini, L., Bellucci, M. and Giunta, F. (2016), "Put your money where your mouth is: real commitment to sustainability and mere rhetoric", Financial Reporting, Vol. 2, pp. 5-31.

Blanc, R., Cho, C.H., Sopt, J. and Branco, M.C. (2019), "Disclosure responses to a corruption scandal: the case of Siemens AG", Journal of Business Ethics, Vol. 156 No. 2, pp. 545-561.

Boiral, O. (2013), "Sustainability reports as simulacra? A counter-account of A and A+ GRI reports", Accounting, Auditing \& Accountability Journal, Vol. 26 No. 7, pp. 1036-1071.

Breitinger, D. and Bonardi, J.P. (2019), "Firms, breach of norms, and reputation damage", Business and Society, Vol. 58 No. 6, pp. 1143-1176.

Brennan, N.M. and Merkl-Davies, D.M. (2014), "Rhetoric and argument in social and environmental reporting: the dirty laundry case", Accounting, Auditing \& Accountability Journal, Vol. 27 No. 4, pp. 602-633.

Brown, T.J. and Dacin, P.A. (1997), "The company and the product: corporate associations and consumer product responses", The Journal of Marketing, Vol. 61 No. 1, pp. 68-84.

Brown, J., Dillard, J. and Hopper, T. (2015), “Accounting, accountants, and accountability regimes in pluralistic societies: taking multiple perspectives seriously", Accounting, Auditing and Accountability Journal, Vol. 28 No. 5, pp. 626-650.

Brunsson, N. (1989), The Organization of Hypocrisy. Talk, Decisions, and Actions in Organizations, John Wiley and Sons, Chichester.

Brunsson, N. (1990), "Deciding for responsibility and legitimation: alternative interpretations of organizational decision-making", Accounting, Organizations and Society, Vol. 15 Nos 1/2, pp. 47-59.

Brunsson, N. (1993), "Ideas and actions: justification and hypocrisy as alternatives to control", Accounting, Organizations and Society, Vol. 18 No. 6, pp. 489-506.

Brunsson, N. (2002), The Organization of Hypocrisy, Abstrakt Liber Copenhagen Business School Press, Oslo, Norway.

Brunsson, N. (2007), The Consequences of Decision-Making, Oxford University Press, Oxford. 
Bryman, A. and Bell, E. (2015), Business Research Methods, Oxford University Press, Oxford.

Buhr, N. (1998), "Environmental performance, legislation and annual report disclosure: the case of acid rain and Falconbridge", Accounting, Auditing \& Accountability Journal, Vol. 11 No. 2, pp. 163-190.

Busco, C. and Quattrone, P. (2015), "Exploring how the balanced scorecard engages and unfolds: articulating the visual power of accounting inscriptions", Contemporary Accounting Research, Vol. 32 No. 3, pp. 1236-1262.

Cavanagh, S. (1997), "Content analysis: concepts, methods and applications”, Nurse Researcher, Vol. 4 No. 3, pp. 5-13.

Chen, J.C. and Roberts, R.W. (2010), "Toward a more coherent understanding of the organizationsociety relationship: a theoretical consideration for social and environmental accounting research", Journal of Business Ethics, Vol. 97 No. 4, pp. 651-665.

Cho, C.H., Michelon, G. and Patten, D.M. (2012), "Impression management in sustainability reports: an empirical investigation of the use of graphs", Accounting and the Public Interest, Vol. 12, pp. 16-37.

Cho, C.H., Roberts, R.W. and Patten, D.M. (2010), "The language of US corporate environmental disclosure", Accounting, Organizations and Society, Vol. 35 No. 4, pp. 431-443.

Cho, C.H., Laine, M., Roberts, R.W. and Rodrigue, M. (2015), "Organized hypocrisy, organizational façades, and sustainability reporting", Accounting, Organizations and Society, Vol. 40, pp. 78-94.

Christensen, L.T., Morsing, M. and Thyssen, O. (2013), "CSR as aspirational talk", Organization, Vol. 20 No. 3, pp. 372-393.

Clarkson, P.M., Li, Y., Richardson, G. and Vasivari, F. (2011), "Does it really pay to be green? Determinants and consequences of proactive environmental strategies", Journal of Accounting and Public Policy, Vol. 30 No. 2, pp. 122-144.

Coombs, W.T. (2007), "Protecting organization reputations during a crisis: the development and application of situational crisis communication theory", Corporate Reputation Review, Vol. 10 No. 3, pp. 163-176.

Coombs, W.T. and Holladay, S., J. (2014), "How publics react to crisis communication efforts: comparing crisis response reactions across sub-arenas", Journal of Communication Management, Vol. 18 No. 1, pp. 40-57.

Coupland, C. (2006), "Corporate social and environmental responsibility in web-based reports: currency in the banking sector?", Critical Perspectives on Accounting, Vol. 17 No. 7, pp. 865-881.

Davis, D.F., Golicic, S.L. and Boerstler, C.N. (2011), "Benefits and challenges of conducting multiple methods research in marketing", Journal of the Academy of Marketing Science, Vol. 39 No. 3, pp. 467-479.

Dean, D.H. (2004), "Consumer reaction to negative publicity: effects of corporate reputation, response, and responsibility for a crisis event", The Journal of Business Communication, Vol. 41 No. 2, pp. 192-211.

Deegan, C. (2002), "The legitimizing effect of social and environmental disclosures - a theoretical foundation", Accounting, Auditing and Accountability Journal, Vol. 15 No. 3, pp. 282-311.

Delmas, M.A. and Burbano, V.C. (2011), "The drivers of greenwashing", California Management Review, Vol. 54 No. 1, pp. 64-87.

Denedo, M., Thomson, I. and Yonekura, A. (2017), "International advocacy NGOs, counter accounting, accountability and engagement", Accounting, Auditing and Accountability Journal, Vol. 30 No. 6, pp. 1309-1343.

Dey, C., Russell, S. and Thomson, I. (2011), "Exploring the potential of shadow accounts in problematising institutional conduct", in Osbourne, S. and Ball, A. (Eds), Social Accounting and Public Management: Accountability for the Common Good, Routledge, Abingdon, pp. 64-75.

Dowling, J. and Pfeffer, J. (1975), "Organizational legitimacy: social values and organizational behavior”, Pacific Sociological Review, Vol. 18 No. 1, pp. 122-136.

Restoring an eroded legitimacy 
AAAJ 34,9

Dumay, J., de Villiers, C., Guthrie, J. and Hsiao, P.C. (2018), “Thirty years of Accounting, Auditing and Accountability Journal: a critical study of the journal's most cited articles", Accounting, Auditing \& Accountability Journal, Vol. 31 No. 5, pp. 1510-1541.

Eisenberg, E.M. (1984), “Ambiguity as strategy in organizational communication”, Communication Monographs, Vol. 51 No. 3, pp. 227-242.

Gallhofer, S., Haslam, J. and Monk, E. (2006), "The emancipatory potential of online reporting. The case of counter accounting", Accounting, Auditing \& Accountability Journal, Vol. 19 No. 5, pp. 681-718.

Gallhofer, S., Haslam, J. and Yonekura, A. (2015), "Accounting as differentiated universal for emancipatory praxis: accounting delineation and mobilisation for emancipation(s) recognising democracy and difference", Accounting, Auditing and Accountability Journal, Vol. 28 No. 5, pp. 846-874.

García-Gavilanes, R., Mollgaard, A., Tsvetkova, M. and Yasseri, T. (2017), "The memory remains: understanding collective memory in the digital age", Science Advances, Vol. 3 No. 4, pp. 1-7.

Glozer, S. and Morsing, M. (2020), "Helpful hypocrisy? Investigating 'double-talk' and irony in CSR marketing communications", Journal of Business Research, Vol. 114, pp. 363-375.

Griffin, M., Babin, B.J. and Attaway, J.S. (1991), "An empirical investigation of the impact of negative public publicity on consumer attitudes and intentions", Advances in Consumer Research, Vol. 18, pp. 334-341.

Guidry, R.P. and Patten, D.M. (2010), "Market reactions to the first-time issuance of corporate sustainability reports: evidence that quality matters", Sustainability Accounting, Management and Policy Journal, Vol. 1 No. 1, pp. 33-50.

Guthey, E. and Morsing, M. (2014), "CSR and the mediated emergence of strategic ambiguity”, Journal of Business Ethics, Vol. 120, pp. 555-569.

Guthrie, J., Petty, R., Yongvanich, K. and Ricceri, F. (2004), "Using content analysis as a research method to inquire into intellectual capital reporting", Journal of Intellectual Capital, Vol. 5 No. 2, pp. 282-293.

Hildebrand, D., DeMotta, Y., Sen, S. and Valenzuela, A. (2017), "Consumer responses to corporate social responsibility (CSR) contribution type”, Journal of Consumer Research, Vol. 44 No. 4 , pp. 738-758.

Holsti, O.R. (1969), Content Analysis for the Social Sciences and Humanities, Addison-Wesley, Holsti Reading, Mass.

Hooghiemstra, R. (2000), "Corporate communication and impression management - new perspectives why companies engage in corporate social reporting", Journal of Business Ethics, Vol. 27 No. 1, pp. 55-68.

Hoque, Z., Parker, L.D., Covaleski, M.A. and Haynes, K. (Eds) (2017), The Routledge Companion to Qualitative Accounting Research Methods, Taylor and Francis.

Jahn, J. and Brühl, R. (2019), "Can bad news be good? On the positive and negative effects of including moderately negative information in CSR disclosures", Journal of Business Research, Vol. 97, pp. 117-128.

Joutsenvirta, M. (2011), "Setting boundaries for corporate social responsibility: firm-NGO relationship as a discursive legitimation struggle", Journal of Business Ethics, Vol. 102 No. 1 , pp. 57-75.

Krippendorff, K. (2004), Content Analysis: An Introduction to its Methodology, Sage, London.

Kuruppu, S.C. and Milne, M.J. (2010), "Dolphin deaths, organizational legitimacy and potential employees' reactions to assured environmental disclosures", Accounting Forum, Vol. 34 No. 1, pp. 1-19.

Kuruppu, S.C., Milne, M.J. and Tilt, C.A. (2019), "Gaining, maintaining and repairing organisational legitimacy”, Accounting, Auditing \& Accountability Journal, Vol. 32 No. 7, pp. 2062-2087. 
Laine, M. and Vinnari, E. (2017), "The transformative potential of counter accounts: a case study of animal rights activism", Accounting, Auditing \& Accounatbilit Journal, Vol. 30 No. 7, pp. 1481-1510.

Lauwo, S., Kyriacou, O. and Julius Otusanya, O. (2019), "When sorry is not an option: CSR reporting and 'face work' in a stigmatised industry - a case study of Barrick (Acacia) gold mine in Tanzania", Critical Perspectives on Accounting, Vol. 71, pp. 1-23.

Lederman, R.P. (1991), "Content analysis of word texts", MCN: The American Journal of Maternal/ Child Nursing, Vol. 16 No. 3, p. 169.

Lee, Y.J., Yoon, H.J. and O'Donnell, N.H. (2018), "The effects of information cues on perceived legitimacy of companies that promote corporate social responsibility initiatives on social networking sites", Journal of Business Research, Vol. 83, pp. 202-214.

Lin-Hi, N. and Muller, K. (2013), "The CSR bottom line: preventing corporate social responsibility", Journal of Business Research, Vol. 66 No. 10, pp. 1928-1936.

Lindblom, C.K. (2010), "The implications of organizational legitimacy for corporate social performance and disclosure", in Gray, R., Bebbington, J. and Gray, S. (Eds), Social and Environmental Accounting, Sage, London, Vol. 2.

Linsley, P. and Kajuter, P. (2008), "Restoring reputation and repairing legitimacy: a case study of impression management in response to a major risk event at Allied Irish Banks plc", International Journal of Financial Services Management, Vol. 3 No. 1, pp. 65-82.

Magness, V. (2006), "Strategic posture, financial performance and environmental disclosure: an empirical test of legitimacy theory", Accounting, Auditing and Accountability Journal, Vol. 19 No. 4, pp. 540-563.

Makela, H. and Nasi, S. (2010), "Social responsibilities of MNCs in downsizing operations", Accounting Auditing \& Accountability Journal, Vol. 23 No. 2, pp. 149-174.

Manetti, G. and Bellucci, M. (2016), "The use of social media for engaging stakeholders in sustainability reporting”, Accounting, Auditing \& Accountability Journal, Vol. 29 No. 6, pp. 985-1011.

McDonald, L.M., Sparks, B. and Glendon, A.I. (2010), "Stakeholder reactions to company crisis communication and causes", Public Relations Review, Vol. 36 No. 3, pp. 263-271.

Menon, G., Jewell, R.D. and Unnava, H.R. (1999), "When a company does not respond to negative publicity: cognitive elaboration vs negative affect perspective", Advances in Consumer Research, Vol. 26 No. 1, pp. 325-329.

Milne, M.J., Tregidga, H. and Walton, S. (2009), "Words not actions! the ideological role of sustainable development reporting", Accounting, Auditing and Accountability Journal, Vol. 22 No. 8, pp. 1211-1257.

Milne, M.J. and Gray, R. (2013), "W(h)ither ecology? The triple bottom line, the global reporting initiative, and corporate sustainability reporting", Journal of Business Ethics, Vol. 118 No. 1, pp. 13-29.

Milne, G.K. and Gray, R. (2007), "Future prospects for corporate sustainability reporting”, in Unerman, J., Bebbingotn, J. and O'Dwyer, B. (Eds), Sustainability Accounting and Accountability, Routledge, New York, NY, pp. 184-207.

Milne, M.J. and Patten, D.M. (2002), "Securing organizational legitimacy: an experimental decision case examining the impact of environmental disclosures", Accounting, Auditing \& Accountability Journal, Vol. 15 No. 3, pp. 372-405.

Mitchell, R.K., Agle, B.R. and Wood, D.J. (1997), "Toward a theory of stakeholder identification and salience: defining the principle of who and what really counts", Academy of Management Review, Vol. 22 No. 4, pp. 853-886.

Morning, M. and Schultz, M. (2006), "Corporate social responsibility communication: stakeholder information, response and involvement strategies", Business Ethics: A European Review, Vol. 15 No. 4, pp. 323-338.
Restoring an eroded legitimacy 
Neu, D., Warsame, H. and Pedwell, K. (1998), "Managing public impressions: environmental disclosures in annual reports", Accounting, Organizations and Society, Vol. 23 No. 3, pp. 265-282.

O'Donovan, G. (2002), "Environmental disclosures in the annual report", Accounting, Auditing \& Accountability Journal, Vol. 15 No. 3, pp. 344-371.

O'Dwyer, B., Unerman, J. and Hession, E. (2005), "User needs in sustainability reporting: perspectives of stakeholders in Ireland”, European Accounting Review, Vol. 14 No. 4, pp. 759-787.

Patten, D.M. (2012), "White tigers, zoos and sustainability reporting: a cynical reflection”, Social and Environmental Accountability Journal, Vol. 32 No. 1, pp. 17-25.

Patten, D.M. (1992), "Intra-industry environmental disclosures in response to the Alaskan oil spill: a note on legitimacy theory", Accounting, Organizations and Society, Vol. 17, pp. 471-475.

Preston, A.M., Wright, C. and Young, J.J. (1996), "Imag(in)ing annual reports", Accounting, Organizations and Society, Vol. 21 No. 1, pp. 113-137.

Rodríguez, L.C. and LeMaster, J. (2007), "Voluntary corporate social responsibility disclosure: SEC 'CSR Seal of Approval”, Business and Society, Vol. 46 No. 3, pp. 370-384.

Romenti, S., Murtarelli, G. and Valentini, C. (2014), "Organisations' conversations in social media: applying dialogue strategies in times of crises", Corporate Communications: An International Journal, Vol. 19 No. 1, pp. 10-33.

Ruffing, L. (2007), "Silent vs. shadow reports: what can we learn from BP's sustainability report versus the financial times?", Social and Environmental Accountability Journal, Vol. 27 No. 1, pp. 9-16.

Schmitt, M., Gollwitzer, M., Förster, N. and Montada, L. (2004), "Effects of objective and subjective account components on forgiving", The Journal of Social Psychology, Vol. 144 No. 5, pp. $465-486$.

Schönbach, P. (1990), Account Episodes. The Management of Escalation of Conflict, Cambridge University Press, Cambridge.

Schultz, F., Utz, S. and Göritz, A. (2011), "Is the medium the message? Perceptions of and reactions to crisis communication via twitter, blogs and traditional media”, Public Relations Review, Vol. 37 No. 1, pp. 20-27.

Scott, S.V. and Walsham, G. (2005), "Reconceptualizing and managing reputation risk in the knowledge economy: toward reputable action", Organization Science, Vol. 16 No. 3, pp. 308-322.

Sethi, S.P. (1977), Advocacy Advertising and Large Corporations: Social Conflict, Big Business Image, the News Media, and Public Policy, D.C. Heath, Lexington, MA.

Shklar, J.N. (1984), Ordinary Vices, Harvard University Press, Cambridge.

Suchman, M.C. (1995), "Managing legitimacy: strategic and institutional approaches", Academy of Management Review, Vol. 20 No. 3, pp. 571-610.

Szabo, S. and Webster, J. (2020), "Perceived greenwashing: the effects of green marketing on environmental and product perceptions”, Journal of Business Ethics, Vol. 171, pp. 719-739, 2021.

Tate, W.L., Ellram, L.M. and Kirchoff, J.F. (2010), "Corporate social responsibility reports: a thematic analysis related to supply chain management", Journal of Supply Chain Management, Vol. 46 No. 1, pp. 19-44.

Thorne, L., Mahoney, L.S. and Manetti, G. (2014), "Motivations for issuing standalone CSR reports: a survey of Canadian firms", Accounting, Auditing \& Accountability Journal, Vol. 27 No. 4, pp. 686-714.

Tilling, M.V. and Tilt, C.A. (2010), "The edge of legitimacy. Voluntary social and environmental reporting in Rothmans' 1956-1999 annual reports”, Accounting, Auditing \& Accountability Journal, Vol. 23 No. 1, pp. 55-81.

Torelli, C.J., Monga, A.B. and Kaikati, A.M. (2012), "Doing poorly by doing good: corporate social responsibility and brand concepts", Journal of Consumer Research, Vol. 38, pp. 948-963. 
Tregidga, H., Milne, M. and Lehman, G. (2012), “Analyzing the quality, meaning and accountability of organizational reporting and communication: directions for future research", Accounting Forum, Vol. 36, pp. 223-230.

Unerman, J. and Chapman, C. (2014), "Academic contributions to enhancing accounting for sustainable development”, Accounting, Organizations and Society, Vol. 39 No. 6, pp. 385-394.

Wagner, T., Lutz, R.J. and Weitz, B.A. (2009), "Corporate hypocrisy: overcoming the threat of inconsistent corporate social responsibility perceptions", Journal of Marketing, Vol. 73, pp. 77-91.

Winkler, P., Etter, M. and Castelló, I. (2019), "Vicious and virtuous circles of aspirational talk: from self-persuasive to agonistic CSR rhetoric", Business and Society, Vol. 1, pp. 98-128.

Zyglidopoulos, S.C. (2001), "The impact of accidents on firms' reputation for social performance", Business and Society, Vol. 40 No. 4, pp. 416-441.

\begin{abstract}
About the authors
Marco Bellucci $(\mathrm{PhD})$ is an assistant professor of accounting in the Department of Economics and Management at the University of Florence. His research interests include sustainability reporting, corporate social responsibility, stakeholder engagement, social enterprises, nonprofit organizations, and accounting history.

Diletta Acuti $(\mathrm{PhD})$ is a senior lecturer in marketing at the University of Portsmouth. Her research interests include sustainable consumer behavior and corporate social responsibility.

Lorenzo Simoni $(\mathrm{PhD})$ is a research fellow in accounting in the Department of Economics and Business Studies at the University of Genoa. His research interests include business model disclosure, nonfinancial information, key performance indicators, risk reporting, and earnings quality.

Giacomo Manetti (PhD) is an associate professor of accounting in the Department of Economics and Management at the University of Florence. His research interests include stakeholder theory, corporate social responsibility, sustainability reporting and assurance, the third sector, and accounting history. Giacomo Manetti is the corresponding author and can be contacted at: giacomo.manetti@unifi.it
\end{abstract}

For instructions on how to order reprints of this article, please visit our website:

www.emeraldgrouppublishing.com/licensing/reprints.htm

Or contact us for further details: permissions@emeraldinsight.com 